\title{
PENERAPAN MODEL PEMBELAJARAN TEAMS GAMES TOURNAMENT DILENGKAPI MEDIA LOGBOOK CHEMISTRY- KARTU DESTINASI UNTUK MENINGKATAN KEAKTIFAN DAN PRESTASI BELAJAR SISWA PADA POKOK BAHASAN ALKANA, ALKENA DAN ALKUNA KELAS X-6 SMAN KEBAKKRAMAT TAHUN AJARAN 2015/2016
}

\author{
Fajar Heri Nurcahyo ${ }^{*}$, Mohammad Masykuri, dan Budi Utami \\ Program Studi Pendidikan Kimia, FKIP,Universitas Sebelas Maret, Surakarta, Indonesia
}

* Keperluan korespondensi, HP : +6285602058410, email: fajarherinurcahyo@student.uns.ac.id

\begin{abstract}
ABSTRAK
Penelitian ini bertujuan untuk: (1) meningkatkan keaktifan siswa dan (2) prestasi belajar siswa melalui penerapan model pembelajaran kooperatif Teams Games Tournament (TGT) dilengkapi media Logbook Chemistry (LogChem)-Kartu Destinasi pada sub pokok bahasan alkana, alkena dan alkuna. Penelitian ini merupakan penelitian tindakan kelas (Classroom Action Research) dengan menggunakan metode analisis data deskriptif kualitatif yang terdiri dari dua siklus dengan tiap siklus terdiri dari perencanaan, pelaksanaan, observasi dan refleksi. Subjek penelitian adalah siswa kelas X-6 SMA Negeri Kebakkramat semester genap tahun ajaran 2015/2016 yang berjumlah 38 siswa terdiri dari 9 laki-laki dan 29 perempuan. Data penelitian berupa data kualitatif dan kuantitatif dengan teknik pengumpulan data menggunakan tes objektif (ranah kognitif siswa), observasi dan angket (afektif dan keaktifan siswa), serta wawancara. Validitas data menggunakan teknik triangulasi. Hasil penelitian menunjukkan bahwa: (1) penerapan model pembelajaran kooperatif Teams Games Tournament (TGT) dilengkapi media Logbook Chemistry (LogChem)-Kartu Destinasi pada sub pokok bahasan alkana, alkena dan alkuna dapat meningkatkan keaktifan siswa. Hal ini berdasarkan hasil penelitian pada siklus I yang menunjukkan bahwa capaian persentase keaktifan siswa sebesar $81,58 \%$. (2) Penerapan model pembelajaran kooperatif Teams Games Tornament (TGT) dilengkapi media Logbook Chemistry (LogChem)-Kartu Destinasi pada sub pokok bahasan alkana, alkena dan alkuna dapat meningkatkan prestasi belajar siswa yang terdiri dari ranah afektif dan kognitif siswa. Hal ini berdasarkan pada persentase capaian ranah afektif siswa siklus I sebesar $89,47 \%$ dan persentase capaian ranah kognitif siswa siklus I sebesar $31,58 \%$ dan meningkat sebesar $60,53 \%$ pada siklus II.
\end{abstract}

Kata kunci: Kartu Destinasi, Keaktifan Siswa, Kognitif Siswa, Logbook Chemistry (LogChem), Teams Games Tournament (TGT)

\section{PENDAHULUAN}

Kimia sebagai bagian dari kurikulum pendidikan menengah mempunyai nilai pendidikan di samping aplikasinya menyentuh berbagai aspek kehidupan manusia [1]. Kimia sebagai mata pelajaran memiliki proses pembelajaran dalam meningkatkan pengetahuan peserta didik yang berkenaan dengan kajian-kajian tentang struktur dan komposisi materi, perubahan yang dapat dialami materi, dan fenomena-fenomena lain yang menyertai perubahan materi [1]. Pembelajaran kimia merupakan serangkaian kegiatan yang melibatkan guru kimia, siswa dan bahan ajar dalam rangka mencapai perubahan yang relatif tetap dalam pengetahuan, sikap, keterampilan dan aspek afektif. Pembelajaran kimia tidak hanya terfokus pada penanaman pengetahuan kimia, tetapi juga mengembangkan kemampuan memecahkan masalah dengan metode 
ilmiah, menumbuhkan sikap ilmiah, membentuk sikap positif terhadap kimia serta memahami dampak lingkungan dan sosial dari aplikasi kimia.

Pembelajaran kimia berbasis TCL (Teacher Centered Learning) masih banyak diterapkan dalam proses pembelajaran di kelas dengan alasan pembelajaran TCL adalah praktis dan tidak banyak menyita waktu. Guru hanya menyajikan materi secara teoritik dan abstrak. Akibatnya, siswa cenderung pasif, hanya mendengarkan guru ceramah di depan kelas dan aktivitas siswa menjadi rendah. Selain itu, akibat dari kebiasaan tersebut siswa menjadi kurang aktif dan kurang kreatif dalam memecahkan suatu masalah, partisipasi rendah, kerja sama dalam kelompok tidak optimal, kegiatan belajar mengajar tidak efisien dan pada akhirnya prestasi belajar menjadi rendah.

Berdasarkan hasil wawancara tanggal 17 Maret 2016 dengan guru kimia kelas $X$ menyatakan bahwa banyak siswa kelas $X$ di SMAN Kebakkramat sudah responsif dalam mata pelajaran kimia, hanya saja masih ada beberapa kelas yang siswanya belum responsif dalam menerima pelajaran, pasif dan aktivitas siswanya masih rendah. Hal ini disebabkan oleh materi kimia yang tergolong sulit bagi sebagian siswa, sehingga banyak siswa yang kesulitan menerima materi pelajaran. Beberapa materi konseptual dan hafalan seperti senyawa hidrokarbon banyak siswa yang mengalami kesulitan dan hal ini berdampak pada nilai atau prestasi belajar siswa. Guru telah memberikan dan menjelaskan materi senyawa hidrokarbon dengan baik, hanya saja siswa tergolong enggan atau malas dalam menghafalkan atau memahami materi senyawa hidrokarbon terutama pada sub pokok bahasan alkana, alkena dan alkuna.

Prestasi belajar siswa kelas X SMA Negeri Kebakkramat tergolong rendah menurut Kriteria Ketuntasan Minimal (KKM) untuk mata pelajaran kimia yakni 75 , terutama kelas X-6. Berdasarkan nilai ujian akhir sekolah semester ganjil tahun ajaran 2015/2016 diketahui bahwa jumlah siswa kelas X-6 yang tuntas 0 siswa dan siswa yang belum tuntas 38 siswa.

Berdasarkan keadaan tersebut, penerapan model pembelajaraan kooperatif Teams Games Tournament (TGT) dilengkapi Logbook Chemistry (LogChem)-Kartu Destinasi dapat membantu siswa dalam meningkatkan keaktifan dan prestasi belajar siswa. Keunggulan model pembelajaraan kooperatif TGT ialah mengandung unsur permainan agar pembelajaran tidak menjenuhkan, komunikasi multi arah dan penguatan yang dapat meningkatkan peran siswa sebagai tutor sebaya untuk dapat saling berdiskusi dalam memecahkan masalah di dalam kelompok kecil, sehingga siswa menjadi paham dengan materi pelajaran yang telah disampaikan. TGT merupakan tipe pembelajaran kooperatif yang menggabungkan kegiatan kelompok dengan kompetensi kelompok [2]. Berdasarkan penelitian Leonard dan Kusumaningsih [3] diperoleh bahwa rata-rata peningkatan prestasi belajar siswa pada kelas yang menggunakan model pembelajaran kooperatif tipe TGT lebih tinggi dibandingkan dengan kelas yang menggunakan model pembelajaran konvensional. Penelitian yang dilakukan oleh Winarto dan Sukarmin [4] diperoleh hasil bahwa pembelajaran dengan TGT dapat meningkatkan hasil belajar siswa.

Selain itu, penelitian ini menggunakan media pembelajaran berupa logbook dan Kartu Destinasi. Penggunaan media ini didasarkan bahwa keaktifan dan prestasi belajar siswa dapat ditingkatkan melalui pra pembelajaran dan saat pembelajaran di sekolah. Pra pembelajaran menggunakan logbook yang diberi nama Logbook Chemistry (LogChem). Tujuan LogChem ialah sebelum siswa menerima pelajaran di sekolah, sebelumnya sudah membaca materi pelajaran di rumah atau sebelum pelajaran di mulai. Dengan membaca terlebih dahulu siswa akan mempunyai modal informasi. Guru akan memberikan materi keesokan harinya di sekolah. Melalui stimulus atau informasi yang berulang, jaringan saraf akan dapat diperkuat, sehingga respon saraf terjadi dengan cepat. Perspektif neurosains kognitif aktivitas belajar melibatkan 
pembentukan dan penguatan koneksi dan jaringan saraf [5].

Penerapan Logbook Chemistry (LogChem) dapat membantu siswa dalam mengetahui gambaran umum materi. Logbook mirip dengan buku catatan yang berfungsi sebagai catatan siswa dan pendeteksi kesulitan belajar siswa setelah membaca materi. Berdasarkan hasil penelitian Torabi et. al. [6], menunjukan bahwa penggunaan logbook berguna untuk belajar interaktif dan dapat meningkatkan nilai oral pada mahasiswa kedokteran gigi. Penggunaan logbook sebagai media pembelajaran juga didukung oleh penelitian yang dilakukan oleh Dafloff et. al. [7], menunjukan bahwa penggunaan logbook dapat meningkatkan pengetahuan dan mengurangi kelemahan mahasiswa kesehatan. Penelitian serupa yang dilakukan oleh Yaghobian et. al. [8], dihasilkan bahwa penggunaan logbook juga dapat meningkatkan kualitas mahasiswa pendidikan kesehatan.

Permainan Kartu Destinasi merupakan inovasi dari permainan ular tangga. Dalam papan permainan ini tidak terdapat ular tangga, melainkan hanya berisi nomor saja [9]. Kartu Destinasi merupakan salah satu media pembelajaran yang dapat digunakan di kelas. Media ini sangat efektif untuk mengajar siswa yang masih senang dengan permainan. Kartu Destinasi merupakan permainan yang memodifikasi permainan ular tangga dengan warna tertentu saja. Tiap warna mengandung pertanyaan yang wajib dijawab oleh peserta. Dengan demikian, siswa dapat belajar sambil bermain Kartu Destinasi ini. Saat pembelajaran, media Kartu Destinasi melalui sistem games dan turnamen dilakukan menjelang jam pelajaran berakhir, dengan maksud proses pembelajaran yang di dalamnya terdapat unsur permainan dan kompetisi akan memacu siswa untuk aktif dan berkontribusi dalam materi pelajaran, sehingga suasana pelajaran akan menyenangkan dan tidak menjenuhkan bagi siswa.

\section{METODE PENELITIAN}

Penelitian ini merupakan Penelitian Tindakan Kelas (PTK) atau Classroom Action Research (CAR) yang dilakukan oleh peneliti dan berkolaborasi dengan guru mata pelajaran yang bersangkutan.

Rancangan solusi permasalahan yakni dengan menggunakan model kooperatif TGT dengan media pembelajaran Logbook Chemistry (LogChem)-Kartu Destinasi, dengan tujuan untuk meningkatkan keaktifan dan prestasi belajar siswa pada sub pokok bahasan alkana, alkena dan alkuna.

Subjek penelitian adalah siswa kelas X-6 SMA Negeri Kebakkramat semester genap tahun ajaran 2015/2016 dengan jumlah siswa 38 orang, terdiri dari 9 laki-laki dan 29 perempuan. Objek pada penelitian ini kualitas proses dan prestasi belajar siswa. Kualitas proses yakni keaktifan siswa dan prestasi belajar siswa yang terdiri dari ranah afektif dan kognitif siswa. Data yang diperoleh pada penelitian ialah keaktifan dan prestasi belajar siswa. Teknik pengumpulan data terdiri dari teknik tes dan teknik non tes (observasi, angket dan tes) [10]. Instrumen penelitian terdiri dari instrumen pembelajaran, media pembelajaran dan instrumen penilaian. Instrumen pembelajaran terdiri dari silabus dan rencana pelaksanaan pembelajaran (RPP). Media pembelajaran terdiri dari Logbook Chemistry (LogChem) [11],[12] dan Kartu Destinasi [9]. Instrumen penilaian terdiri dari instrumen afektif, keaktifan dan kognitif siswa. Instrumen afektif dan keaktifan siswa berupa lembar observasi dan angket. Instrumen kognitif siswa berupa tes objektif pilihan ganda. Validitas data menggunakan metode triangulasi [13],[14].

Instrumen penelitian yang terdiri dari angket, observasi dan tes objektif pilihan ganda divalidasi menggunakan formula Gregory [15]. Instrumen tersebut kemudian diujicobakan dan dianalisis hasilnya untuk mengetahui reliabilitas [10],[12], tingkat kesukaran [16],[17] dan daya beda soal [17], [18],[19]. 
Teknik analisis data dalam penelitian ini menggunakan metode modus pada hasil penilaian keaktifan siswa dan prestasi belajar siswa yang dijelaskan secara kualitatif, serta dari skema Miles-Huberman yang menggunakan langkah-langkah reduksi data, penyajian data dan penarikan kesimpulan, serta verifikasi data [13].

Prosedur dan langkah yang digunakan dalam melaksanakan penelitian ini mengikuti model dari Stephen Kemmis dan Mc Teggart dalam [20] berupa model spiral yang meliputi empat komponen diantaranya rencana tindakan (planning), tindakan (acting), pengamatan (observing) dan refleksi (reflecting). Kegiatan ini disebut dengan satu siklus kegiatan pemecahan masalah [21]. Apabila satu siklus belum menunjukkan tanda-tanda perubahan ke arah perbaikan (peningkatan mutu), kegiatan penelitian dilanjutkan pada siklus kedua.

\section{HASIL DAN PEMBAHASAN}

Berdasarkan observasi pra siklus tanggal 17 Maret 2016 yang dilakukan di kelas X-6 SMA Negeri Kebakkramat semester genap tahun ajaran 2015/2016 diperoleh hasil bahwa 2 siswa tidak masuk kelas, 3 siswa terlambat masuk kelas karena masih berada di kantin saat bel pergantian jam pelajaran, 5 siswa tidak membawa buku kimia baik itu LKS maupun buku paket, 2 siswa didapatkan belajar materi selain kimia dan tidak memperhatikan saat guru sedang menjelaskan materi, 2 siswa aktif bertanya materi yang kurang jelas, tidak ada siswa yang berani mengerjakan soal di papan tulis dan menjawab pertanyaan guru tanpa ditunjuk. Berdasarkan temuan tersebut, teridentifikasi bahwa proses pembelajaran masih berpusat pada guru (teacher centered learning). Hal ini mengakibatkan siswa menjadi pasif dan jenuh dalam menerima pelajaran kimia. Siswa kemudian melakukan aktivitas lain seperti bermain gadget dan mengobrol dengan teman sebangkunya. Selain itu, metode diskusi jarang diterapkan di kelas, sehingga interaksi antar siswa menjadi rendah.

\section{Siklus I}

\section{a. Perencanaan}

Tahapan perencanaan tindakan siklus I ialah: (1) meminta silabus mata pelajaran kimia kelas $\mathrm{X}$ kepada guru yang telah disahkan oleh pemerintah, (2) menyusun rencana pelaksanaan pembelajaran (RPP) sub pokok bahasan alkana, alkena dan alkuna yang disesuaikan dengan sintaks model pembelajaran kooperatif TGT, (3) menyiapkan media pembelajaran Logbook Chemistry (LogChem) dan Kartu Destinasi, (4) menyusun instrumen penilaian yang terdiri dari instrumen afektif dan keaktifan siswa berupa lembar observasi dan angket serta instrumen kognitif siswa berupa tes objektif pilihan ganda. Target capaian siklus I pada ranah afektif, keaktifan dan kognitif siswa masing-masing sebesar $50 \%$.

\section{b. Pelaksanaan}

Siklus I dilaksanakan selama 4 kali pertemuan dengan rincian 3 kali pertemuan untuk penyampaian materi dan 1 kali pertemuan untuk evaluasi siklus I.

Pertemuan pertama kegiatan belajar mengajar diawali berdoa bersama. Tahap orientasi guru menyampaikan tujuan pembelajaran dengan menerapkan model pembelajaran kooperatif tipe TGT dilengkapi Kartu Destinasi. Tahap apersepsi guru menyampaikan materi sebelumnya mengenai kekhasan atom karbon, kemudian dilanjutkan pengenalan nama senyawa alkana berikut dengan kegunaannya dalam kehidupan seharihari. Tahap motivasi, guru memberi motivasi bahwa senyawa hidrokarbon memiliki keteraturan yang khas sebagai bukti kebesaran Tuhan YME. Kegiatan inti pada tahap eksplorasi diawali dengan pembagian siswa dalam kelompok diskusi yang terdiri dari 4-5 orang. Setelah siswa berada dalam kelompoknya, guru memberikan instruksi kepada siswa untuk mengeluarkan lembar LogChem Alkana yang di hari sebelumnya telah diberikan ke siswa, kemudian membahas bersama. Setelah membahas LogChem, guru menjelaskan sub pokok bahasan alkana selama 30 menit yang 
terdiri dari pengertian senyawa alkana, rumus umum, deret homolog, gugus dan nama alkil, tata nama senyawa alkana dan tabel sifat fisik alkana. Berdasarkan hasil pengamatan, interaksi antara guru dan siswa terlihat cukup baik jika dibandingkan dengan sebelum pra tindakan (siklus). Siswa mulai terlihat aktif dengan berani bertanya kepada guru khususnya pada tata nama senyawa alkana. Tahap elaborasi guru memberikan soal diskusi kepada siswa. Siswa berdiskusi menganalisis masalah dalam bentuk soal diskusi, menuliskan jawaban soal diskusi di depan kelas dan menjelaskannya sebagai bentuk tukar pikiran antar anggota kelompok. Setelah diskusi dan presentasi selesai, kemudian dilanjutkan turnamen Kartu Destinasi. Sebelumnya guru menjelaskan aturan turnamen Kartu Destinasi. Setiap kelompok turnamen terdiri dari 4-5 anggota turnamen. Urutan penomoran siswa didasarkan pada urutan penomoran kelompok diskusi. Anggota turnamen nomor 1 berkompetisi dengan sesama anggota turnamen nomor 1 dari kelompok lain, anggota nomor 2 berkompetisi dengan anggota nomor 2 dari kelompok lain, dan seterusnya. Kelompok yang menang yaitu apabila salah satu peserta turnamen mencapai garis finish terlebih dahulu. Guru memfasilitasi peserta didik untuk berkompetisi secara sportif dan jujur dalam rangka meningkatkan keaktifan dan prestasi belajar siswa. Kartu soal dalam turnamen ini seputar materi alkana dan pengetahuan umum. Setelah selesai turnamen, guru menyampaikan kesimpulan materi tentang sub pokok bahasan alkana yang telah dipelajari. Guru membagikan LogChem Alkena untuk pertemuan kedua dan memberikan instruksi kepada siswa untuk mempelajari sub pokok bahasan alkena. Guru juga memberikan kesempatan terakhir kepada siswa untuk bertanya bila ada materi yang belum jelas. Guru mengucapkan salam penutup untuk mengakhiri proses kegiatan belajar mengajar pada pertemuan pertama.

Kegiatan belajar mengajar pertemuan kedua sama dengan pertemuan pertama. Perbedaannya terletak pada
LogChem dan kartu soal permainan Kartu Destinasi yang membahas materi alkena. Berdasarkan observasi, siswa terlihat lebih aktif dengan berani bertanya kepada guru khususnya pada penentuan nomor atom karbon dan tata nama senyawa alkena serta berani mengoreksi kesalahan penulisan di papan tulis oleh guru. Kondisi ini berbeda pada saat pertemuan pertama yang menunjukkan bahwa siswa belum berani untuk mengoreksi dan memperbaiki kesalahan tulisan di papan tulis oleh guru. Hal ini menunjukkan bahwa kekritisan dan rasa percaya diri mulai tumbuh dan keaktifan siswa mulai terbentuk dalam proses pembelajaran meskipun masih ada rasa takut untuk memperbaiki kesalahan tulisan di papan tulis. Keadaan tersebut juga membangkitkan rasa percaya diri dan keaktifan siswa lainnya dalam proses pembelajaran bahwa suatu kesalahan itu adalah hal yang wajar.

Kegiatan belajar mengajar pertemuan ketiga sama dengan pertemuan pertama dan kedua. Perbedaannya hanya terletak pada LogChem dan kartu soal turnamen Kartu Destinasi yang membahas materi alkuna. Berdasarkan observasi, Siswa mulai rajin mencatat materi yang dituliskan guru di papan tulis meski ada beberapa siswa yang masih malas untuk mencatat. Kondisi ini lebih baik jika dibandingkan pada pertemuan pertama dan kedua. Hal ini dikarenakan siswa mulai sadar bahwa catatan sangat penting untuk mengulangi pelajaran yang telah disampaikan di kelas. Kondisi ini didukung pula dari keaktifan siswa yang mulai berkembang sejak pertemuan kedua, sehingga memicu siswa lain untuk aktif bertanya dan mencatat agar tidak tersaingi temannya. Siswa juga menyadari bahwa ketika siswa memiliki catatan akan memudahkan mereka dalam menjawab soal turnamen Kartu Destinasi. Mencatat merupakan bentuk keaktifan siswa merekam setiap peristiwa melalui bahasa tulisan yang akan berdampak pada penguatan hafalan siswa dalam memahami materi kimia. Jika dibandingkan pada pertemuan pertama dan kedua siswa terlihat bersemangat dan aktif dalam menjawab soal diskusi. Siswa yang sudah 
mengerjakan soal diskusi, kemudian berebut maju ke depan kelas menuliskan hasil jawaban di papan tulis tanpa ditunjuk oleh guru.

\section{c. Pengamatan}

Data yang diperoleh dalam penelitian ini berupa hasil observasi dan angket untuk ranah afektif dan keaktifan siswa yang diberikan di akhir siklus I, serta hasil tes pilihan ganda yang diberikan di akhir siklus I dan II.

Ranah afektif siswa terdiri dari 5 aspek yaitu sikap, nilai, konsep diri, moral dan minat. Data hasil penelitian ranah afektif siswa secara ringkas dapat dilihat pada Tabel 1 dan 2.

Tabel 1. Ringkasan Hasil Penelitian Ranah Afektif Siswa

\begin{tabular}{clcc}
\hline Siklus & Kategori & $\begin{array}{c}\text { Jumlah } \\
\text { Siswa }\end{array}$ & $\begin{array}{c}\text { Capaian } \\
(\%)\end{array}$ \\
\hline \multirow{4}{*}{ I } & Sangat Baik & 34 & 89,47 \\
& Baik & 4 & 10,53 \\
& Kurang Baik & 0 & 0 \\
& Tidak Baik & 0 & 0 \\
\hline
\end{tabular}

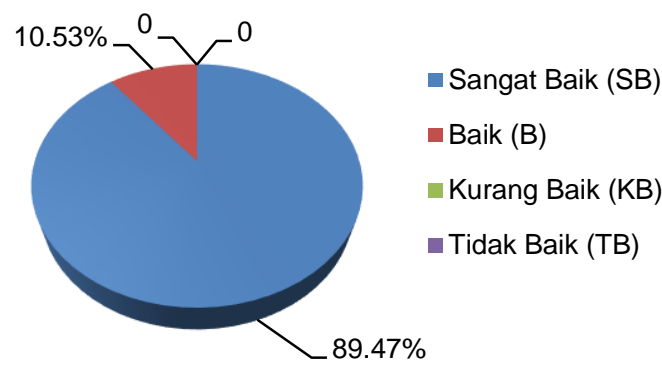

Gambar 1. Diagram Pie Capaian Ranah Afektif Siswa Siklus I

Target capaian ranah afektif siswa siklus I sebesar 50\%. Ketercapaian berhasil apabila jumlah ranah afektif siswa pada kategori "sangat baik" dan "baik" sama dengan atau melebihi target yang telah ditentukan. Berdasarkan Tabel 1 dan Gambar 1 menunjukkan bahwa siklus I diperoleh kategori "sangat baik" sebesar 89,47\% dan kategori "baik" sebesar 10,53\%. Hal ini menunjukkan bahwa siswa telah mencapai aspek sikap, nilai, konsep diri, moral dan minat secara baik yang ditunjukkan dengan mengerjakan tugas, cara belajar, keyakinan atas kemampuan guru, keyakinan atas keberhasilan peserta didik, kemampuan dalam mempelajari materi, kemandirian dalam mengerjakan tugas, kepedulian terhadap teman, kejujuran, kehadiran dalam pembelajaran dan usaha memahami sub pokok bahasan alkana, alkena dan alkuna. Ketercapaian ranah afektif siswa telah mencapai target yang telah. Oleh karena itu, ranah afektif siswa tidak perlu dilanjutkan ke tindakan siklus II.

Keaktifan siswa terdiri dari 5 aspek yaitu oral activities, visual activities, listening activities dan writing activities. Data hasil penelitian keaktifan siswa secara ringkas dapat dilihat pada Tabel 2.

Tabel 2. Ringkasan Hasil Penelitian Keaktifan Siswa

\begin{tabular}{clcc}
\hline Siklus & Kategori & $\begin{array}{c}\text { Jumlah } \\
\text { Siswa }\end{array}$ & $\begin{array}{c}\text { Capaian } \\
(\%)\end{array}$ \\
\hline \multirow{4}{*}{ I } & Sangat Aktif & 14 & 36,84 \\
& Aktif & 17 & 44,74 \\
& Kurang Aktif & 7 & 18,42 \\
& Tidak Aktif & 0 & 0 \\
\hline
\end{tabular}

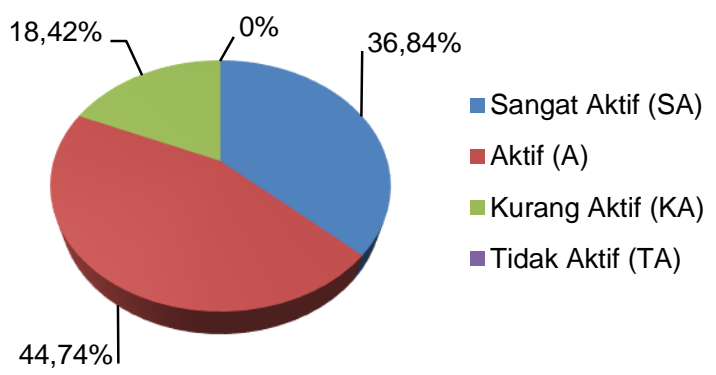

Gambar 2. Diagram Pie Capaian Keaktifan Siswa Siklus I

Target capaian keaktifan siswa siklus I sebesar 50\%. Ketercapaian berhasil apabila jumlah capaian keaktifan siswa pada kategori "sangat aktif" dan "aktif" sama dengan atau melebihi target yang telah ditentukan. Berdasarkan Tabel 2 dan Gambar 2 menunjukkan bahwa siklus I diperoleh kategori sangat aktif sebesar $36,84 \%$ dan kategori aktif sebesar 44,74\%. Jumlah capaian kategori sangat aktif dan aktif sebesar $81,58 \%$. Hal ini menunjukkan bahwa siswa telah mencapai aspek oral activities, visual activities, listening activities dan writing activities secara baik yang ditunjukkan dengan bertanya apabila ada materi yang belum 
dimengerti, memberikan ide selama diskusi kelompok, menjawab pertanyaan guru tanpa ditunjuk, memperhatikan saat pelajaran, memperhatikan siswa lain ketika presentasi atau memberi pendapat, mendengarkan penjelasan materi dari guru, mendengarkan penjelasan dari teman ketika presentasi atau memberi pendapat, mencatat materi, menulis hasil diskusi kelompok dan menulis jawaban di papan tulis tanpa ditunjuk guru. Ketercapaian keaktifan siswa telah mencapai target yang telah ditentukan. Oleh karena itu, keaktifan siswa tidak perlu dilanjutkan ke tindakan siklus II.

Ketercapaian tersebut diperoleh karena penerapan Logbook Chemistry (LogChem) membantu siswa dalam mengetahui gambaran umum materi. Siswa membaca terlebih dahulu materi sebelum guru menyampaikan di sekolah. Siswa juga akan berdiskusi tentang materi yang sudah dipelajari dalam kelompok kecil. Dengan pengalamanpengalaman belajar melalui bantuan logbook dapat meningkatkan prestasi seperti teori Diagram Pengalaman Edgar Dale. Siswa yang membaca materi sampai melakukan presentasi dapat meningkatkan daya ingat sampai $70 \%$ [22]. Hal-hal yang dimasukkan dalam logbook mencakup diantaranya apa yang sudah dibaca, hasil pengamatan dan pemecahan masalah [10]. Hal ini dilakukan agar saat pembelajaran berlangsung dan guru memancing siswa dengan pertanyaan-pertanyaan, siswa akan merespon dan menjawab secara konstan pertanyaan tersebut. Dalam menjawab pertanyaan, awalnya siswa masih menjawab pertanyaan bersama dengan guru. Namun, pada kesempatan lain guru menunjuk salah satu siswa untuk menjawab secara individu hingga siswa menjawab pertanyaan tanpa ditunjuk oleh guru.

Penggunaan model pembelajaran kooperatif TGT sangat membantu dalam meningkatkan keaktifan, interaksi dan pemahaman siswa. Suatu model pembelajaran kooperatif tidak terlepas dengan diskusi kelompok siswa. Model pembelajaran kooperatif TGT menuntut siswa untuk kompak, aktif, interaktif, saling kerjasama dan kontributif dalam kelompok diskusinya untuk membahas dan bertukar ide mengenai materi sub pokok bahasan alkana, alkena dan alkuna. Bekerja dengan siswa-siswa lain dapat membantu mengembangkan kemampuan empatik mereka dengan memberikan kesempatan kepada mereka untuk melihat sudut-sudut pandang orang lain, yang pada gilirannya membantu mereka untuk menyadari bahwa setiap orang memiliki kelebihan dan kekurangan [23]. Kekompakan tersebut akan berdampak ketika turnamen Kartu Destinasi. Secara individu, saat turnamen berlangsung, siswa mewakili masing-masing kelompok diskusinya. Apabila siswa tidak menguasai materi pelajaran, maka akan berdampak pada hasil juara turnamen Kartu Destinasi. Peran serta antar siswa saat diskusi sangat berpengaruh terhadap proses pembelajaran dan penguatan saat turnamen Kartu Destinasi. Penguatan saat turnamen Kartu Destinasi akan membuat pemahaman dan pengalaman belajar siswa menjadi semakin baik. Apabila pemahaman dan pengalaman belajar siswa baik, maka akan berdampak pada prestasi belajar siswa.

Ranah kognitif siswa terdiri dari 4 indikator kompetensi yaitu mengelompokkan senyawa hidrokarbon berdasarkan kejenuhan ikatan; memberi nama senyawa alkana, alkena dan alkuna; menentukan struktur senyawa alkana, alkena dan alkuna; dan menyimpulkan hubungan sifat fisik senyawa hidrokrabon yang terdiri dari titik didih, titik leleh dan kerapatan berdasarkan kenaikan massa atom relatif (Mr). Data hasil penelitian ranah kognitif siswa siklus I secara ringkas dapat dilihat pada Tabel 3.

Tabel 3. Ringkasan Hasil Tes Ranah Kognitif Siswa Siklus I

\begin{tabular}{clcc}
\hline Siklus & Kategori & $\begin{array}{c}\text { Jumlah } \\
\text { Siswa }\end{array}$ & $\begin{array}{c}\text { Capaian } \\
(\%)\end{array}$ \\
\hline \multirow{2}{*}{ I } & Tuntas & 12 & 31,58 \\
& Belum & 26 & 68,42 \\
\hline & Tuntas & & \\
\hline
\end{tabular}




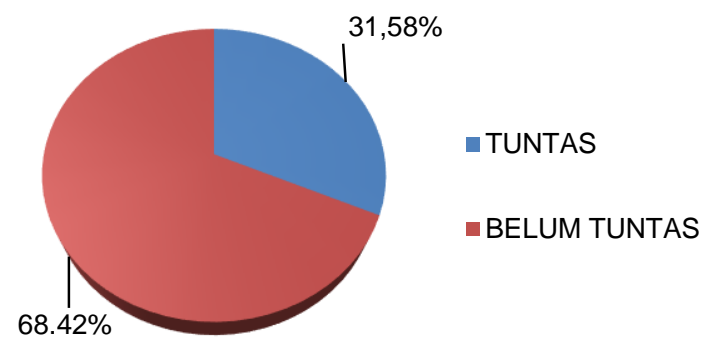

Gambar 3. Diagram Pie Capaian Ketuntasan Belajar Siswa Siklus I

Target capaian ketuntasan belajar siswa siklus I sebesar $50 \%$. Ketercapaian berhasil apabila jumlah siswa kategori "tuntas" sama dengan atau melebihi target yang telah ditentukan. Berdasarkan Tabel 3 dan Gambar 3 menunjukkan bahwa ketuntasan belajar siswa pada siklus I mencapai 12 siswa dari 38 siswa atau sebesar $31,38 \%$ dengan kategori tuntas dan 26 siswa dari 38 siswa atau $68,42 \%$ dengan kategori belum tuntas. Ketercapaian ketuntasan belajar siswa siklus I belum mencapai target yang telah ditentukan. Ketidaktuntasan siswa pada siklus I disebabkan belum tercapainya indikator kompetensi I dan IV yakni mengelompokkan senyawa hidrokarbon berdasarkan kejenuhan ikatan dan menyimpulkan hubungan sifat fisik senyawa hidrokrabon yang terdiri dari titik didih, titik leleh dan kerapatan berdasarkan kenaikan massa atom relatif (Mr). Pada indikator I, jawaban siswa terdapat banyak kesalahan dalam mengelompokkan senyawa hidrokarbon alkana, alkena dan alkuna apabila diketahui rumus molekul dan struktur senyawa tersebut. Selain itu, pada indikator IV, jawaban siswa banyak yang terbalik dalam menentukan rumus alkana dan alkuna dan kesalahan dalam memberi nama struktur senyawa hidrokarbon jika rantai alkilnya lebih dari satu nama alkil.

\section{d. Refleksi}

Berdasarkan hasil siklus I, ketercapaian penilaian ranah afektif dan keaktifan siswa telah mencapai target, sedangkan ranah kognitif siswa belum mencapai target. Hal ini perlu dilakukan perbaikan pembelajaran pada ranah kognitif siswa ke tindakan siklus II.

\section{Siklus II}

\section{a. Perencanaan}

Perencanaan tindakan siklus II didasarkan pada hasil penilaian keseluruhan di siklus I. Siklus II difokuskan pada ranah yang belum mencapai target capaian saja yakni kognitif siswa. Peneliti menyusun RPP siklus II untuk 1 kali pertemuan yang menekankan pada materi yang belum tuntas berdasarkan indikator kompetensi yang telah dibuat pada siklus I, kemudian dikonsultasikan ke guru mata pelajaran kimia untuk mendapat persetujuan dan masukan agar pemahaman siswa terhadap materi yang belum tuntas dapat teratasi dengan baik. Pembagian kelompok diskusi dan turnamen siswa tetap seperti pada siklus I. Jika kelompok diskusi dan turnamen diubah akan berdampak pada hasil juara turnamen nantinya. LogChem tidak disertakan pada siklus II. Target capaian siklus II pada ranah kognitif siswa sebesar $60 \%$.

\section{b. Pelaksanaan}

Siklus II dilaksanakan selama 2 kali pertemuan dengan rincian 1 kali pertemuan untuk penyampaian materi dan 1 kali pertemuan untuk evaluasi siklus II.

Pertemuan pertama kegiatan belajar mengajar di tahap orientasi, apersepsi, motivasi dan kegiatan inti pada tahap eksplorasi sama seperti pada pertemuan-pertemuan di siklus I. Hanya saja pada pertemuan pertama siklus II ini tidak membahas LogChem. Guru mulai menjelaskan sub pokok bahasan alkana dan alkuna selama 45 menit yang terdiri dari pengertian senyawa alkana dan alkuna; rumus umum alkana dan alkuna; deret homolog alkana dan alkuna; gugus dan nama alkil; tata nama senyawa alkana dan alkuna; dan tabel sifat fisik alkana dan alkuna. Setelah selesai menjelaskan materi, guru memberikan kesempatan kepada siswa untuk bertanya. Berdasarkan hasil pengamatan, pada pertemuan ini siswa lebih aktif bertanya terutama pada penamaan 
senyawa karbon. Beberapa siswa juga ada yang bertanya ketika guru sedang menjelaskan materi.

Tahap elaborasi guru memberikan soal diskusi kepada siswa seputar materi alkana dan alkuna. Setelah diskusi dan presentasi selesai, kemudian dilanjutkan turnamen Kartu Destinasi. Kartu soal dalam turnamen ini seputar materi alkana, alkuna dan pengetahuan umum. Pada pertemuan ini pula guru mengakumulasi jumlah menang siswa dalam turnamen Kartu Destinasi siklus I dan II dan memberikan reward ke siswa dengan kategori "peserta turnamen teraktif". Reward yang diberikan kepada para juara berupa sertifikat penghargaan yang ditandatangani oleh peneliti dan guru kimia kelas X. Reward diberikan untuk memotivasi siswa agar lebih giat lagi belajar tentang materi kimia.

\section{c. Pengamatan}

Data hasil penelitian ranah kognitif siswa siklus II secara ringkas dapat dilihat pada Tabel 4.

Tabel 4. Ringkasan Hasil Tes Ranah Kognitif Siswa Siklus II

\begin{tabular}{clcc}
\hline \multirow{2}{*}{ Siklus } & Kategori & $\begin{array}{c}\text { Jumlah } \\
\text { Siswa }\end{array}$ & $\begin{array}{c}\text { Capaian } \\
(\%)\end{array}$ \\
\hline \multirow{2}{*}{ II } & Tuntas & 23 & 60,53 \\
& Belum & 15 & 39,47 \\
& Tuntas & & \\
\hline
\end{tabular}

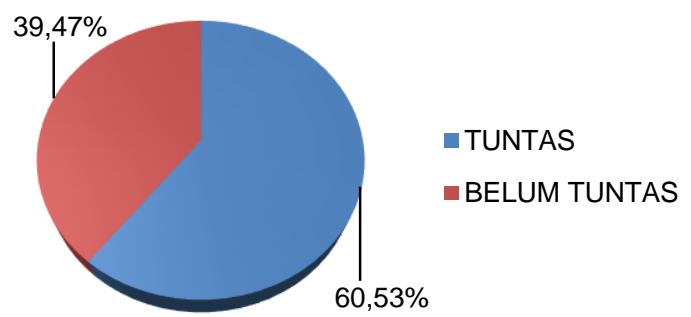

Gambar 4. Diagram Pie Capaian Ketuntasan Belajar Siswa Siklus II

Target capaian ketuntasan belajar siswa siklus I sebesar $50 \%$. Berdasarkan Tabel 4 dan Gambar 4 menunjukkan bahwa ketuntasan belajar siswa siklus II mencapai 23 siswa dari 38 siswa atau sebesar $60,53 \%$ dengan kategori tuntas dan 15 siswa dari 38 siswa atau 39,47\% dengan kategori belum tuntas. Kategori tuntas mengalami peningkatan sebesar $28,95 \%$ di siklus II. Ketercapaian ketuntasan belajar siswa telah mencapai target yang telah ditentukan.

\section{Perbandingan Antar Siklus}

Data hasil penelitian ranah kognitif siswa siklus I dan II secara ringkas dapat dilihat pada Tabel 5.

Tabel 5. Ringkasan Hasil Tes Ranah Kognitif Siswa

\begin{tabular}{clcc}
\hline Siklus & Kategori & $\begin{array}{c}\text { Jumlah } \\
\text { Siswa }\end{array}$ & $\begin{array}{c}\text { Capaian } \\
(\%)\end{array}$ \\
\hline \multirow{2}{*}{ I } & Tuntas & 12 & 31,58 \\
& Belum & 26 & 68,42 \\
& Tuntas & & 60,53 \\
\hline \multirow{2}{*}{ II } & Tuntas & 23 & 60,53 \\
& Belum & 15 & 39,47 \\
\hline & Tuntas & & \\
\hline
\end{tabular}

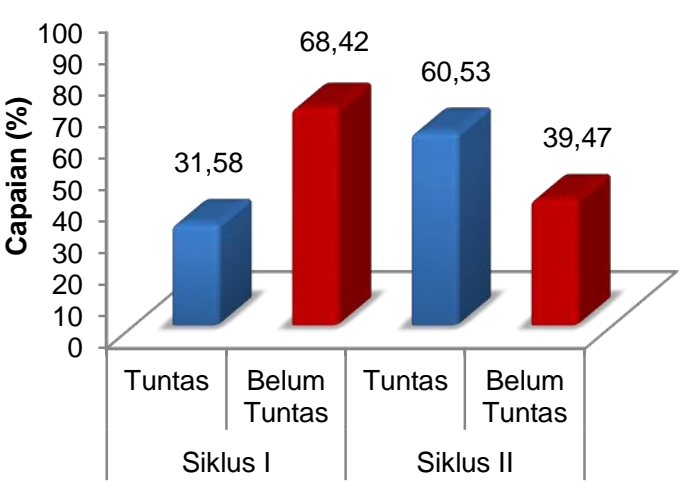

Gambar 5. Grafik Perbandingan Capaian Ketuntasan Belajar Siswa Siklus I dan II

Berdasarkan Tabel 5 dan Gambar 5 menunjukkan bahwa ketuntasan belajar siswa pada kategori "tuntas" mengalami peningkatan sebesar $28,95 \%$ di siklus II. Persentase capaian kategori tuntas pada siklus II telah tercapai dari target yang ditentukan yakni sebesar $60 \%$.

Berdasarkan hasil tersebut dapat disimpulkan bahwa model pembelajaran tipe TGT dilengkapi Logbook Chemistry (LogChem)-Kartu Destinasi dapat meningkatkan keaktifan dan prestasi belajar siswa kelas X-6 SMAN Kebakkramat semester genap tahun ajaran 2015/2016 pada sub pokok bahasan alkana, alkena dan alkuna. 


\section{KESIMPULAN}

Berdasarkan hasil penelitian dan pembahasan, kesimpulan pada penelitian ini adalah (1) penerapan model pembelajaran kooperatif TGT dilengkapi media Logbook Chemistry (LogChem)Kartu Destinasi pada sub pokok bahasan alkana, alkena dan alkuna dapat meningkatkan keaktifan siswa. Hal ini berdasarkan pada persentase capaian pada siklus I sebesar $81,58 \%$ yang telah memenuhi target capaian sebesar 50\%; (2) penerapan model pembelajaran kooperatif TGT dilengkapi media Logbook Chemistry (LogChem)-Kartu Destinasi pada sub pokok bahasan alkana, alkena dan alkuna dapat meningkatkan prestasi belajar siswa. Prestasi belajar dalam penelitian ini terdiri dari ranah afektif dan kognitif siswa. Hal ini berdasarkan pada persentase capaian ranah afektif siswa siklus I sebesar $100 \%$ dan persentase capaian ranah kognitif siswa siklus I sebesar $31,58 \%$ dan meningkat sebesar $60,53 \%$ pada siklus II.

\section{UCAPAN TERIMAKASIH}

Penulis ucapkan terimakasih kepada Bapak Drs. Jaka Wismono, M.Pd. yang telah memberikan ijin untuk penelitian di kelas X-6 SMA Negeri Kebakkramat Semester Genap Tahun Ajaran 2015/2016 dan Ibu Ida Lastari, S.T. yang telah membantu selama proses penelitian berlangsung.

\section{DAFTAR RUJUKAN}

[1] Firman, H. (2007). Pendidikan Kimia. Dalam Tim Pengembang IImu Pendidikan UPI. IImu dan Aplikasi Pendidikan. (hlm. 221-242). Bandung: PT. Imperial Bhakti Utama.

[2] Slavin, R. E. (2010). Cooperative Learning Teori, Riset dan Praktik. Terjemahan Nurulita Yusron. Bandung: Nusa Media.

[3] Leonard \& Kusumaningsih, K. D. (2009). Pengaruh Model Pembelajaran Kooperatif Tipe Teams
Games Tournaments (TGT) terhadap Peningkatan Hasil Belajar Biologi pada Konsep Sistem Pencernaan Manusia. Jurnal IImiah Exacta, 2 (1), 83-98.

[4] Winarto, R. T. \& Sukarmin. (2012). Penerapan Zuma Chemistry Game dengan Kooperatif Tipe TGT (Teams Games Tournament) pada Materi Unsur, Senyawa Campuran di MTsN Surabaya II. Unesa Journal of Chemical Education, 1(1), 180-188.

[5] Schunk, D. H. (2012). Teori-teori Pembelajaran: Perspektif Pendidikan Edisi Keenam. Jakarta: Pustaka Pelajar.

[6] Torabi, K., Bazrafkan, L., Sepehri, S., Hashemi, M. (2013). The Effect of Logbook as a Study Guide in Dentistry Training. J. Adv Med\&Prof., 1(3):81-84.

[7] Dafloff, Tsilingaridis, \& Hindbeck. (2004). A Logbook for Continuous Self-Assessment During 1 Year in Paediatric Dentistry. European Journal of Paediatric Dentistry. 3, 163-169.

[8] Yaghobian, M., Fakhri, M., Salmeh, F. (2011). Assesment of the Effect of Logbook on Nursing and Midwifery Student Clinical Skills. Middle East Journal of Science Research. 7 (6), 896-902.

[9] Rahmawati, D. K. (2008). Studi Komparasi Pembelajaran Kimia Menggunakan Metode TGT (Teams Games Tournament) dengan Media Roda Impian dan Destinasi Terhadap Prestasi Belajar Siswa pada Materi Pokok Reaksi Redoks Kelas X Semester II SMA Negeri 1 Wonosari Tahun Ajaran 2008/2009. Skripsi Tidak Dipublikasikan, Fakultas Keguruan dan Ilmu Pendidikan, Universitas Sebelas Maret, Surakarta.

[10] Sudijono, A. (2005). Pengantar Evaluasi Pendidikan. Jakarta: PT. Raja Grafindo Persada. 
[11] Asrori , M. (2007). Penelitian Tindakan Kelas. Bandung: CV. Wawacana Prima.

[12] Pratama, W. M, N. C. S, Agung \& Mulyani, Bakti. (2015). Penerapan Metode Pembelajaran Student Teams Achievement Division (STAD) dilengkapi Media Log Book Chesmistry (Logchem) untuk Meningkatkan Kemandirian dan Prestasi Belajar Siswa pada Materi Koloid Kelas XI MIA SMAN 1 Banyudono Tahun Pelajaran 2014/2015. Jurnal Pendidikan Kimia (JPK), Vol. 4 No. 4 Tahun 2015, 180 185.

[13] Sugiyono. (2010). Metode Penelitian Pendidikan (Pendekatan Kuantitatif, Kualitatif, dan $R$ \& D). Bandung: Alfabeta.

[14] Suwandi, Sarwiji. 2008. Penelitian Tindakan Kelas dan Penulisan Karya IImiah. Modul Pendidikan dan Pelatihan Profesi Guru (PLPG). Panitia Sertifikasi Guru Rayon 13 : Surakarta.

[15] Gregory. (2007). Psychological. Testing. New York: Pearson Education.

[16] Daryanto. (2012). Evaluasi Pendidikan. Jakarta: Rineka Cipta.

[17] Depdiknas. (2009). Analisis Butir Soal. Jakarta: Direktorat Pendidikan Menengah Umum.

[18] Kusaeri \& Suprananto. (2012). Pengukuran dan Penilaian Pendidikan. Yogyakarta: Graha IImu.

[19] Sudijono. (2008). Pengantar Evaluasi Pendidikan. Jakarta: PT. Raja Grafindo Persada.

[20] Subyantoro. (2009). Penelitian Tindakan Kelas. Semarang: CV. Widya Karya.
[21] Arikunto, S., Suhardjono \& Supardi. (2011). Strategi Menyusun Penelitian Tindakan Kelas. Jakarta: Andi Offset.

[22] Sanjaya, W. (2013). Perencanaan dan Desain Sistem Pembelajaran. Jakarta: Prenadamedia Group.

[23] Muijs, Daniel, dan Reynold, D. (2008). Effective Teaching. Yogyakarta: Pustaka Pelajar. 